\title{
Modulation of inflammation in transgenic models of Alzheimer's disease
}

\author{
Amy M Birch ${ }^{\dagger}$, Loukia Katsouri ${ }^{\dagger}$ and Magdalena Sastre ${ }^{*}$
}

\begin{abstract}
Over the past decade the process of inflammation has been a focus of increasing interest in the Alzheimer's disease (AD) field, not only for its potential role in neuronal degeneration but also as a promising therapeutic target. However, recent research in this field has provided divergent outcomes, largely due to the use of different models and different stages of the disease when the investigations have been carried out. It is now accepted that microglia, and possibly astrocytes, change their activation phenotype during ageing and the stage of the disease, and therefore these are important factors to have in mind to define the function of different inflammatory components as well as potential therapies. Modulating inflammation using animal models of AD has offered the possibility to investigate inflammatory components individually and manipulate inflammatory genes in amyloid precursor protein and tau transgenics independently. This has also offered some hints on the mechanisms by which these factors may affect AD pathology. In this review we examine the different transgenic approaches and treatments that have been reported to modulate inflammation using animal models of AD. These studies have provided evidence that enhancing inflammation is linked with increases in amyloid-beta (A $\beta$ ) generation, $A \beta$ aggregation and tau phosphorylation. However, the alterations on tau phosphorylation can be independent of changes in $A \beta$ levels by these inflammatory mediators.
\end{abstract}

Keywords: Inflammation, Microglia, Astrocytes, Amyloid, Tau, Transgenics, Anti-inflammatory

\section{Background}

During the last 10 years, interest in research related to Alzheimer's disease (AD) and inflammation has grown significantly. Ageing is the greatest risk factor for development of $\mathrm{AD}$ and this is thought, in part, to be due to enhanced chronic inflammation associated with increasing age [1]. In addition, it has been recognised that amyloid-beta $(A \beta)$ is able to initiate an inflammatory response, which implicates the activation of microglia and the recruitment of astrocytes, and therefore the release of cytokines, chemokines, reactive oxygen species and neurotoxic products that have been involved in neuronal and synaptic damage [2]. Mice expressing mutant amyloid precursor protein (APP) or tau do not present significant neuronal loss; therefore, it has been theorised that the addition of the inflammatory component of $\mathrm{AD}$ would result in a more appropriate model to investigate the disease. Due to the well-documented changes in

\footnotetext{
* Correspondence: m.sastre@imperial.ac.uk

${ }^{\dagger}$ Equal contributors

Division of Brain Sciences, Imperial College London, London W12 ONN, UK
}

inflammatory markers detected in the AD brain and the inflammatory risk factors associated with the disease, targeting these processes has become increasingly attractive and the use of anti-inflammatory drugs has shown potential as a preventive treatment. In this review we aim to describe different genetic and drug manipulations that have been carried out in AD animal models and that have allowed the identification of mechanisms by which inflammation is a relevant factor to incorporate as a hallmark for AD pathology.

\section{Modelling Alzheimer's disease}

It is now widely accepted that $A \beta$ induces glial activation and therefore mouse models of Alzheimer's disease overexpressing the human APP with familial AD mutations, such as the Tg2567 and the APP23 (both carrying the Swedish mutation, $\mathrm{APP}_{\mathrm{SWE}}$ ), have been shown to present microglial and astrocytic activation [3,4]. In addition, their brains display enhanced levels of cytokines such as TNF $\alpha$, IFN $\gamma$, IL- $1 \beta$, IL- $1 \alpha$, chemoattractant protein-1, cyclooxygenase (COX)-2 and complement component 
1q $[2,3,5]$. The characterisation of inflammatory processes in the APPV717I mouse model has demonstrated that focal glial activation occurs before amyloid plaque formation, already at 3 months of age [6], in parallel with decreased LTP (long-term potentiation) [7]. However, there have been some issues on how well these mouse models mimic human pathology because they do not show the robust tauopathy and neuronal death that is evident in the human disease unless additional human transgenes such as tau are added [8]. The triple-transgenic model (3×Tg-AD), which harbours $\mathrm{APP}_{\mathrm{SWE}}$, presenilin-1 (PS1 $\left.1_{\mathrm{M} 146 \mathrm{~V}}\right)$ mutation, and tau mutation ( $\left.\operatorname{tau}_{\mathrm{P} 301 \mathrm{~L}}\right)$, offers the advantage of developing progressive plaque deposition and tangle formation together with microglial activation and an upregulation of the pro-inflammatory cytokine TNF $\alpha$ and chemokine MCP-1 (CCL2), although this is limited to the entorhinal cortex [9].

Mouse models of tauopathy such as the P301S tau transgenic (Tg) mouse also exhibit neuroinflammatory changes, exemplified by the co-localisation of aggregated tau, IL-1 $\beta$ and COX-2, reactive astrocytosis and the accumulation of activated microglial cells around taupositive neuronal cells [10]. Interestingly, microglial activation precedes tangle formation in 3-month-old P301S $\mathrm{Tg}$ mice [11], and therefore neuroinflammation has been proposed to be the link between $A \beta$ deposition and the formation of neurofibrillary tangles.

Perhaps one of the more promising advances in modelling AD comes from the development of a rat model that coexpresses the human $\mathrm{APP}_{\mathrm{SWE}}$ and PS1 $\Delta \mathrm{E} 9$ [12]. These TgF344-AD rats develop all the hallmarks typically seen in Tg-AD mice (age-dependent cerebral amyloidosis, glial activation, and memory impairments) but additionally exhibit tauopathy and neuronal death and therefore more closely mimic human AD pathology. This model provides further support for the amyloid cascade hypothesis and it is hoped that it will provide a next step in translational therapeutic studies for AD and further enhance understanding of the basic neuropathology and the underlying causes of this disease.

Activated glial cells can be imaged in vivo in animal models of AD using positron emission tomography. The development of tracers for activated microglia is based on the observation that the peripheral benzodiazepine receptor is upregulated in activated microglia. Ligands such as $\left[{ }^{11} \mathrm{C}\right](\mathrm{R})-\mathrm{PK} 11195$ bind to this receptor, also known as the translocator protein (TSPO). A significant age-dependent increase in specific $\left[{ }^{3} \mathrm{H}\right](\mathrm{R})$-PK11195 binding was demonstrated in a transgenic mouse model of $\mathrm{AD}$ by autoradiography (TASTPM: $\mathrm{APP}_{\mathrm{sw}} \mathrm{xPS} 1_{\mathrm{M} 146 \mathrm{~V}}$; [13]). However, [ $\left.{ }^{11} \mathrm{C}\right]-(\mathrm{R})-\mathrm{PK} 11195$ positron emission tomography could not demonstrate differences between wildtypes and transgenic APP/PS1 mice [14]. This tracer has some limitations, such as high non-specific binding and high binding to plasma proteins. These issues have consequently led to the development of new radiotracers targeting TSPO including $\left[{ }^{18} \mathrm{~F}\right]-\mathrm{PBR} 111,{ }^{11} \mathrm{C}$-radiolabelled and ${ }^{18}$ F-radiollabeled versions of PBR06 and PBR28 as well as $\left[{ }^{18} \mathrm{~F}\right]$-FEPPA [15]. In fact, radiolabelling of TSPO with $\left[{ }^{11} \mathrm{C}\right] \mathrm{AC}-5216$ was linearly proportional to the amount of phospho-tau immunolabelling in transgenic PS19 mice carrying the P301S tau mutation [16]. The results of that study indicated that TSPO immunoreactivities are more likely to be associated with neurofibrillary tangles rather than $\mathrm{A} \beta$ deposits.

\section{Modulation of inflammatory processes in models of Alzheimer's disease}

Modulation in amyloid precursor protein transgenic models

Genetic manipulation of several immune and inflammatory pathways in mouse models of $\mathrm{AD}$ has been carried out during the past decade to explore how increasing or decreasing neuroinflammation may affect AD progression (see Table 1). Unfortunately, most of these reports have focused only on the effect on amyloid deposition and there is a general lack of cognitive and longitudinal live imaging studies. These investigations have provided some indications to potential mechanisms by which inflammation may trigger changes in AD pathology. However, there has been some variability in the results obtained from these studies, which are largely dependent upon in which transgenic mouse model the studies have been carried out. For example, deletion of inducible nitric oxide synthase (iNOS) in an APP/PS1 background resulted in different outcomes on $A \beta$ load compared to iNOS knockout in the Tg2576 mouse model $[17,18]$. In general it is expected that overexpression of pro-inflammatory mediators will enhance progression of the disease and therefore treatments should follow an anti-inflammatory approach. For example, blocking signaling of the pro-inflammatory cytokines IL-12 and IL-23 via ablation of the common subunit p40 in APP/PS1 mice has been shown to reduce glial activation and amyloid burden [19]. Furthermore, IFN $\gamma$ signaling loss in APP mice knockout for IFN $\gamma$ receptor type I (GRKO mice) reduced gliosis and amyloid plaques in $\mathrm{Tg} 2576$ mice [20]. Interestingly, a significant reduction in the number of BACE1-positive astrocytes was seen in APP/GRKO mice as compared with APP littermates. In line with this, deletion of TNFRI in APP23 mice has been reported to reduce BACE1 protein levels and activity as well [21]. These studies in animal models support our in vitro observations, which showed that inflammation enhances BACE1 expression [22,23].

Another potential way by which inflammation may contribute to $\mathrm{AD}$ pathology is by increasing $\mathrm{A} \beta$ aggregation. Nitration of $A \beta$ has been shown to accelerate its aggregation and was detected in the core of $A \beta$ plaques 
Table 1 Modulation of inflammatory mediators in Alzheimer's disease mouse models

\begin{tabular}{|c|c|c|c|}
\hline AD mouse model & Genetic manipulation & Effect on Alzheimer-like pathology & Reference \\
\hline $\mathrm{APP}^{2} 3^{1}$ & TNF-RI-/- & $\downarrow A \beta, \downarrow$ amyloid plaques, $\downarrow$ microglial activation, $\downarrow$ BACE1,$\downarrow$ neuronal loss, $\uparrow$ memory & [21] \\
\hline $3 \times \operatorname{Tg}-A D^{2}$ & TNF-RI/RII-/- & $\uparrow A \beta, \uparrow a m y l o i d ~ p l a q u e s, ~ \uparrow P H F, \downarrow \mid B A 1, \downarrow$ microglial phagocytosis, $\downarrow$ LTP & [24] \\
\hline $3 \times \operatorname{Tg}-A D^{2}$ & TNFa-l- & $\uparrow A \beta, \leftrightarrow$ memory improvement & [25] \\
\hline $3 \times \operatorname{Tg}^{-}-A D^{2}$ & TglL-1 $\beta^{\text {XAT }}$ & $\downarrow A \beta, \uparrow p-t a u, \uparrow g l i a l$ activation & [26] \\
\hline $\mathrm{APP} / \mathrm{PS} 1^{3}$ & TglL-1 $\beta^{\text {XAT }}$ & $\downarrow A \beta, \uparrow g l i a l$ activation, $\uparrow c y$ tokines & {$[27]$} \\
\hline $\mathrm{APP} / \mathrm{PS} 1^{3}$ & TglL-1 $\beta^{\text {XAT }}$ & $\downarrow A \beta, \downarrow$ amyloid plaques & {$[28]$} \\
\hline APP/PS1 $1^{4}$ & $\mid \mathrm{LL}-12 \mathrm{a}-/-$ & $\downarrow A \beta$ & [19] \\
\hline APP/PS1 $1^{4}$ & IL-12 $\beta-/-$ & $\downarrow A \beta, \downarrow$ glial activation & [19] \\
\hline $\mathrm{APP} / \mathrm{PS} 1^{4}$ & |L-23-/- & $\downarrow A \beta$ & [19] \\
\hline PDGF-APP Swelnd line $19^{5}$ & GFAP-TGF $\beta 1$ & $\downarrow A \beta, \uparrow c e r e b r o v a s c u l a r A \beta, \uparrow$ glial activation & [29] \\
\hline PDAPP $^{6}$ & GFAP-TGF $\beta 1$ & $\uparrow$ cerebrovascular $\mathrm{A} \beta, \uparrow C A \mathrm{~A}, \uparrow$ perivascular astrocytes & [30] \\
\hline $\operatorname{Tg} 2576^{7}$ & CD11C-DNR(TGF- $\beta$ ) & $\downarrow A \beta, \downarrow$ memory impairment, $\downarrow C A A$ & [31] \\
\hline $\operatorname{Tg} 2576^{7}$ & $|F N \gamma R|-/-$ & $\downarrow A \beta, \downarrow g$ lial activation & {$[20]$} \\
\hline $\mathrm{APP} / \mathrm{PS} 1^{3}$ & Mrp14-/- & $\downarrow A \beta, \downarrow B A C E 1, \downarrow c y$ tokines, $\uparrow$ microglial activation, $\uparrow A \beta$ phagocytosis & [32] \\
\hline $\operatorname{Tg} 2576^{7}$ & NOS2-I- & $\uparrow A \beta, \uparrow p$-tau, $\uparrow$ neuronal death & {$[17]$} \\
\hline $\mathrm{APP} / \mathrm{PS} 1^{3}$ & NOS2-/- & $\downarrow A \beta, \downarrow$ plaques, $\uparrow L T P, \uparrow m e m o r y$ & [18] \\
\hline $\mathrm{APP} / \mathrm{PS} 1^{3}$ & NOS2-/- & $\uparrow I D E$ & [33] \\
\hline $\operatorname{Tg}-\mathrm{SwDI} / \mathrm{B}^{8}$ & NOS2-/- & $\leftrightarrow A \beta, \uparrow p$-tau, $\uparrow C A A, \uparrow$ neuronal loss, $\uparrow$ memory impairment & [34] \\
\hline PDGF-APP Swelnd line $J 9^{5}$ & PDGF-RAGE & $\uparrow A \beta, \uparrow$ glial activation, $\downarrow L T P$ & [35] \\
\hline PDGF-APP Swelnd line $J 9^{5}$ & GFAP-a1-ACT & $\uparrow A \beta$ & [36] \\
\hline PDAPP $^{6}$ & GFAP-a1-ACT & $\uparrow A \beta$, $\uparrow$ plaques & [37] \\
\hline PDAPP $^{6}$ & GFAP-a1-ACT & $\uparrow p$-tau & [38] \\
\hline
\end{tabular}

${ }^{1}$ hAPP Swedish mutation under the murine Thy1.2 promoter. ${ }^{2}$ hAPP Swedish, hPS1 knock-in with M146V mutation, htau P301L mutation. APP and Tau are under the Thy 1 promoter. ${ }^{3}$ hAPP Swedish and hPS1dE9 mutations under the murine Thy 1.2 promoter. ${ }^{4}$ hAPP Swedish and hPS1 L166P mutations under the murine Thy 1 promoter. ${ }^{5} \mathrm{hAPP}$ Swedish and Indiana mutations under the PDGF promoter. ${ }^{6} \mathrm{hAPP}$ Indiana mutation under the PDGF promoter. ${ }^{7} \mathrm{hAPP}$ Swedish mutation under the hamster prion promoter. ${ }^{8} \mathrm{hAPP}$ Swedish, Dutch and lowa mutations under the murine Thy 1.2 promoter. $A \beta$, amyloid-beta; $A C T$, antichymotrypsin; $A D$, Alzheimer's disease; APP, amyloid precursor protein; CAA, cerebral amyloid angiopathy; GFAP, glial fibrillary acidic protein; IBA, ionized calcium binding adaptor molecule-1; IDE, insulin degrading enzyme; IFN, interferon; IL, interleukin; LTP, long-term potentiation; NOS, nitric oxide synthase; PDAPP, amyloid precursor protein under control of plateletderived growth factor promoter; PDGF, platelet-derived growth factor; PHF, Paired helical filament; RAGE, Receptor for Advanced Glycation End; Tg, transgenic; TGF, transforming growth factor; TNF, tumor necrosis factor.

of APP/PS1 mice and AD brains. Studies carried out in nitric oxide synthase (NOS) 2 knockout mice have shown strongly decreased $3 \mathrm{NTyr}(10)-\mathrm{A} \beta$, overall $\mathrm{A} \beta$ deposition and cognitive dysfunction in APP/PS1 mice [18].

A recently studied and significant factor in immune response is the NLRP3 inflammasome, which is a multiprotein oligomer consisting of caspase 1, PYCARD, NALP and sometimes caspase 5. It is upregulated in response to the stimulation of macrophages with pathogen-associated molecule patterns. APP/PS1 mice crossed with NLRP3-/mice have rescued spatial memory, synaptic plasticity and a reduction in $A \beta$ load when compared with age-matched APP/PS1 mice. These changes were associated with an increase in microglial phagocytic activity and increased insulin degrading enzyme [39]. APP/PS1 mice deficient in NLRP3 show increased M2 phenotype markers: FIZZ1, arginase-1, and IL-4, with reduced NOS2 expression. Complementary results were also shown with deletion of caspase 1 , an important effector enzyme, in APP/PS1 mice [39].
Yet, intriguingly, many studies that induce an inflammatory state by administration of lipopolysaccharide (LPS) or IL- $1 \beta$ lead to a decrease in A $\beta$ burden. This effect has been associated with enhanced microglial activation and subsequent $A \beta$ clearance [27,28,40-42]. This is a seemingly artificial method of activation of microglia, however, as acute administration of these strongly activating factors does not mimic the chronic inflammation shown in AD and, as IL- $1 \beta$ and LPS induce memory impairments in rodents $[43,44]$, they could never be thought of as a viable therapy.

In summary, studies in APP models have shown that inflammation may potentiate AD pathology in APP transgenic mice by increasing $A \beta$ generation, aggregation and by affecting its clearance.

\section{Modulation in tau models}

There is a scarcity of studies directly assessing the effect of inflammation in tau models of $\mathrm{AD}$. The few that have 
been conducted have led to some intriguing results that suggest there may be immune responses to APP processing and tau hyperphosphorylation. While APP or APP/ PS1 models do not develop neurofibrillary tangles, they do show increased tau phosphorylation $[45,46]$. Products of inflammation, such as pro-inflammatory cytokines, can change the substrate specificity of kinases/phosphatases leading to tau phosphorylation at pathological sites [47].

Unlike the increases in $\mathrm{A} \beta$ pathology shown in PDAPP J20 [48], suppression of inflammation by overexpressing the complement inhibitory factor sCrry in P301L tau Tg mice resulted in reduced tau pathology [49]. This suggests that acute activation of the complement activation pathway is detrimental in tau mice. The $3 \times \mathrm{Tg}-\mathrm{AD}$ mouse model has also been used to test the effect of manipulating inflammation on tau pathology. Acute activation of the immune response in $3 \times \mathrm{Tg}$-AD mice by LPS treatment induced tau hyperphosphorylation via a Cdk5-dependent mechanism [50]; however, no changes were detected in amyloid pathology. In line with this, viral infectioninduced acute or chronic inflammation in $3 \times \mathrm{Tg}-\mathrm{AD}$ mice significantly exacerbated tau pathology and led to impairments in spatial memory. In this case, tau phosphorylation was increased via a glycogen synthase kinase- $3 \beta$-dependent mechanism [51]. Other approaches to induce inflammation in the brain of the $3 \times \mathrm{Tg}-\mathrm{AD}$ mice such as by controlled cortical impact traumatic brain injury caused acute intraaxonal $A \beta$ accumulation and increased phospho-tau [52]. Interestingly, and in contrast to that which is observed for transgenic mice overexpressing only APP, IL- $1 \beta$ overexpression in $3 \times \mathrm{Tg}-\mathrm{AD}$ mice resulted in increased tau phosphorylation, associated with higher p38 MAPK and GSK3 $\beta$ activity with reductions in $A \beta$ load [26].

However, other studies have shown controversial results in this $3 \times \mathrm{Tg}-\mathrm{AD}$ model, reporting reduced tau phosphorylation after delivery of IFN $\gamma$ (rAAV1-IFN $\gamma$ ) via recombinant adeno-associated virus vector [53]. In addition, disruption of TNF $\alpha$ signaling in $3 \times \mathrm{Tg}-\mathrm{AD}$ exacerbated amyloid and tau pathology [24,54].

With these last few exceptions, the results of modulation of inflammation in tau transgenics suggest that increased neuroinflammation leads to enhanced phosphorylation of tau, and this effect is not necessarily dependent on increased $\mathrm{A} \beta$ generation.

\section{Glial modulation in Alzheimer's disease models Microglia manipulation in Alzheimer's disease models}

The microglial/macrophage response is a key mediator of the immune response in the brain. Microglia can be activated following exogenous or endogenous stimulation by a variety of receptors. Stimulation of these receptors can induce activation of microglia into a 'classical (M1)' or 'alternative (M2)' phenotype. That microglia play a significant role in eliciting inflammation and clearing toxic products and damaged tissue cannot be disputed, but their direct role in disease progression is unclear. Near complete ablation of microglia, by crossing either APP23 or APP/PS1 mice with CD11b-TK mice, did not show differences in plaque formation and only a very small reduction in diffuse $A \beta$ in the APP23/CD11b-TK model [55], suggesting more subtle approaches to study their role are necessary.

A number of recent reviews have highlighted the current literature trends and debated the seemingly contradictory results relating to microglial involvement in AD [56-58]. The activation state of microglia and their ability to phagocytose and clear amyloid in the brain seems to be a significant, but contentious, factor. Microglia and macrophages express a number of different receptors that can promote phagocytosis and clearance of $\mathrm{A} \beta$ that have been targeted. These include complement receptors, scavenger receptors, and cytokine/chemokine receptors that are associated with pathogen recognition (Table 2). These data can often seem incompatible and contradictory in many cases and yet yield some significant therapeutic targets and emphasize the multi-faceted and heterozygous nature of microglial response in $\mathrm{AD}$ from the beginning of the disease throughout its progression. Specific manipulation of signaling factors associated with a shift to the M2 phenotype is reported to promote clearance of $\mathrm{A} \beta$ and ameliorate other symptoms, as microglia exhibit a more anti-inflammatory, phagocytic phenotype. For example, suppression of fractalkine signaling, a negative regulator of microglial activation, is successful in reducing amyloid plaque burden and neuronal loss [59-62]. In mouse models of other neurodegenerative disease such as Parkinson's disease or ALS (amyotrophic lateral sclerosis), lack of CX3CR1 causes widespread neuron loss [63], suggesting that the microglial activation profile seen here is an AD-specific effect. However, as APP mouse models do not exhibit significant neuron loss it is difficult to conclude if this is a tau-specific effect or relevant to human AD.

In addition, targeting of the phagocytic phenotype of microglia has shown some promising results in AD mouse models. The complement pathway has been extensively studied in relation to $\mathrm{AD}$ and reports suggest that upregulating complement factors may target inflammatory processes by promoting migration and phagocytosis of inflammatory cells $[48,71,75]$.

Microglia and macrophages express a number of receptors that can promote clearance of $A \beta$, such as scavenger receptor class A1 (Scara1) and class BI (Scarb1). Knockout models for Scarb1 [65] and Scara1 [64] have shown alterations in $\mathrm{A} \beta$ load.

Additionally, Toll-like receptors (TLRs) and their coreceptors including MD-2, CD14, and CD36 [90] are of great importance for the recognition of pathogens in the body and participate in the response of microglial cells 
Table 2 Modulation of glia in Alzheimer's disease mouse models

\begin{tabular}{|c|c|c|c|}
\hline AD mouse model & $\begin{array}{c}\text { Genetic } \\
\text { manipulation }\end{array}$ & Effect on Alzheimer-like pathology & Reference \\
\hline $\mathrm{APP} / \mathrm{PS} 1^{1}$ & Scara1-/- & $\uparrow A \beta, \uparrow m o r t a l i t y, \downarrow I D E, \downarrow N e p r i l y s i n$ & [64] \\
\hline 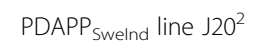 & Scarb1-/- & $\uparrow$ amyloid plaques, $\uparrow$ CAA, $\leftrightarrow$ glial activation, $\uparrow$ memory impairment & [65] \\
\hline $\mathrm{APP} / \mathrm{PS} 1^{3}$ & CD11b-TK & $\leftrightarrow A \beta, \leftrightarrow$ amyloid plaques, $\uparrow$ GFAP, $\downarrow$ lba 1 & [55] \\
\hline APP $23^{4}$ & CD11b-TK & $\downarrow A \beta, \downarrow l$ ba $1, \leftrightarrow$ amyloid plaques & [55] \\
\hline PDAPP $_{\text {swelnd }}$ line $\mathrm{J}_{2} \mathrm{O}^{2}$ & CXCR3-GFP ki & $\leftrightarrow A \beta, \uparrow$ microglial activation, $\uparrow \mathrm{LL}-6, \uparrow T N F-a, \uparrow p-t a u, \uparrow m e m o r y ~ i m p a i r m e n t$ & [62] \\
\hline $\operatorname{TgCRND8}^{5}$ & CXCR3-GFP ki & $\downarrow A \beta, \downarrow$ amyloid plaques, $\uparrow$ microglial phagocytosis, $\uparrow$ microglial proliferation & [59] \\
\hline $\mathrm{APP} / \mathrm{PS} 1^{3}$ & CXCR3-GFP ki & $\downarrow A \beta, \downarrow$ amyloid plaques, $\downarrow$ microglia, $\uparrow$ microglial phagocytosis & {$[60]$} \\
\hline $\mathrm{R} 1.40^{6}$ & CXCR3-GFP ki & $\downarrow A \beta, \downarrow$ amyloid plaques & {$[60]$} \\
\hline htau ${ }^{7}$ & CXCR3-GFP ki & $\begin{array}{c}\uparrow p \text {-tau, } \uparrow \text { Gallyas-positive dystrophic neurites, } \downarrow \text { lba1, } \uparrow \text { microglial activation }\left(\mathrm{CD} 68^{+} \text {and }\right. \\
\left(\mathrm{CD} 45^{+}\right)\end{array}$ & [66] \\
\hline $3 \times \operatorname{Tg}-A D^{8}$ & CXCR3-GFP ki & $\downarrow$ neuronal loss & [61] \\
\hline $\operatorname{Tg} 2576^{9}$ & Ccr2-l- & $\uparrow A \beta, \downarrow N E P$ & [67] \\
\hline APP/PS $1^{10}$ & Ccr2-l- & $\uparrow$ soluble $A \beta, \uparrow$ microglial activation, $\uparrow$ memory impairment & {$[68]$} \\
\hline $\mathrm{APP} / \mathrm{PS} 1^{10}$ & NSE-COX2 & $\uparrow A \beta, \uparrow P G E 2$ & [69] \\
\hline $\operatorname{Tg} 2576^{9}$ & $\mathrm{C} 1 \mathrm{q}-/-$ & $\leftrightarrow \mathrm{A} \beta, \downarrow$ glial activation, $\uparrow$ neuronal degeneration & {$[70]$} \\
\hline $\operatorname{Tg} 2576^{9}$ & $\mathrm{C} 1 \mathrm{q}-/-$ & $\leftrightarrow A \beta, \downarrow g$ lial activation, $\downarrow$ loss of synaptic markers & [71] \\
\hline $\mathrm{APP} / \mathrm{PS} 1^{11}$ & $\mathrm{C} 1 \mathrm{q}-/-$ & $\leftrightarrow \mathrm{A} \beta, \downarrow$ glial activation & [71] \\
\hline TaU $_{\text {P301L line JNLP3 }}{ }^{12}$ & sCrry & $\uparrow p$-tau & [49] \\
\hline $\operatorname{Tg} 2576^{9}$ & CD40L-/- & $\downarrow p$-tau & [72] \\
\hline $\operatorname{Tg} 2576^{9}$ & CD40L-/- & $\downarrow A \beta, \downarrow g l i a l$ activation & {$[73,74]$} \\
\hline APP/PS1 $1^{11}$ & CD40L-/- & $\downarrow A \beta, \downarrow g l i a l$ activation & [73] \\
\hline $\mathrm{APP} / \mathrm{PS} 1^{1}$ & Nlrp3-/- & $\downarrow A \beta, \downarrow$ plaques, $\downarrow$ IL-1 $\beta, \downarrow$ iNOS, $\uparrow L T P, \uparrow$ spatial memory, $\uparrow$ IDE & [39] \\
\hline PDAPP $_{\text {Swelnd }}$ line $J 20^{2}$ & C3-/- & 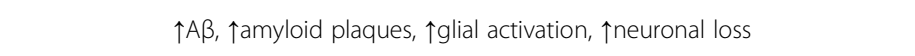 & [75] \\
\hline $\mathrm{APP} / \mathrm{PS} 1^{1}$ & CD14-/- & $\downarrow A \beta, \downarrow$ amyloid plaques, $\downarrow C D 45^{+}$activated microglia & [76] \\
\hline APP/PS1 ${ }^{1}$ & CD33-/- & $\downarrow A \beta, \downarrow$ plaques & [77] \\
\hline $\begin{array}{l}\operatorname{Tg} 2576^{9} \text { (before plaque } \\
\text { onset) }\end{array}$ & CD36-/- & $\leftrightarrow A \beta, \leftrightarrow R O S$ & [78] \\
\hline $\operatorname{Tg} 2576^{9}$ (old mice) & CD36-/- & $\downarrow A \beta_{40}, \downarrow C A A, \uparrow$ cognitive performance & [79] \\
\hline $\mathrm{APP} / \mathrm{PS} 1^{1}$ & CD45-/- & $\uparrow A \beta, \uparrow a m y l o i d$ plaques, $\uparrow$ inflammatory microglia, $\uparrow$ TNF- $\alpha, \uparrow I L-1 \beta, \uparrow$ neuronal death & {$[80]$} \\
\hline APP $/ P S 1^{3}$ & $\mid R A K 4^{K / K I}$ & $\downarrow A \beta, \downarrow$ amyloid plaques, $\downarrow$ glial activation, $\uparrow$ PPARY, $\uparrow I D E, \uparrow I F N \gamma, \downarrow$ iNOS & [81] \\
\hline $\mathrm{APP} / \mathrm{PS} 1^{1}$ & TLR4 ${ }^{\text {Lps-d }}$ & $\uparrow A \beta, \uparrow a m y l o i d ~ p l a q u e s$ & [82] \\
\hline $\mathrm{APP} / \mathrm{PS} 1^{1}$ & TLR4 ${ }^{\text {Lps-d }}$ & $\uparrow C D 11 b^{+}$microglia, $\uparrow G F A P$ & [83] \\
\hline $\mathrm{APP} / \mathrm{PS} 1^{1}$ & TLR4 ${ }^{\text {Lps-d }}$ & $\uparrow A \beta, \uparrow$ amyloid plaques, $\downarrow$ microglial activation, $\uparrow$ cognitive impairment & [84] \\
\hline $\mathrm{APP} / \mathrm{PS} 1^{1}$ & MyD88-/- & $\downarrow A \beta, \downarrow$ amyloid plaques, $\downarrow C D 11 b^{+}, C D 45^{+}$microglia & [85] \\
\hline APP/PS1 ${ }^{10}$ & MyD88+/- & $\downarrow$ amyloid plaques, $\uparrow$ soluble $A \beta, \downarrow \| L-1 \beta$ & [86] \\
\hline APP/PS1 $1^{10}$ & TLR2-/- & Delayed plaque formation, $\uparrow A \beta, \uparrow T G F-\beta, \uparrow$ memory impairment & [87] \\
\hline $\operatorname{Tg} 2576^{9}$ & GFAP-MCP1 & $\uparrow A \beta, \uparrow m i c r o g l i a l$ activation & {$[88]$} \\
\hline $\mathrm{APP} / \mathrm{PS} 1^{1}$ & GFAP-/-Vim-/- & 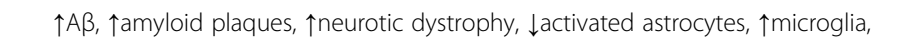 & [89] \\
\hline
\end{tabular}

${ }^{1}$ hAPP Swedish and hPS1dE9 mutations under the murine Thy1.2 promoter. ${ }^{2}$ hAPP Swedish and Indiana mutations under the PDGF promoter. ${ }^{3}$ hAPP Swedish and hPS1 L166P mutation under the Thy 1 promoter. ${ }^{4} \mathrm{hAPP}$ Swedish mutation under the murine Thy 1.2 promoter. ${ }^{5} \mathrm{hAPP}$ Swedish and Indiana mutations under the hamster prion promoter. ${ }^{6} \mathrm{YAC}$ with $300 \mathrm{~Kb}$ hAPP gene with the Swedish mutation. ${ }^{7} \mathrm{Mapt}-/-$ mice crossed with Tg(MAPT)8cPdav that contains the whole 5 'flanking and exons 1-14 of the hMAPT gene. ${ }^{8}$ hAPP Swedish mutation, hPS1 knock-in with M146V mutation, htau P301L mutation. hAPP and hTau are under the Thy 1 promoter. ${ }^{9} \mathrm{hAPP}$ Swedish mutation under the hamster prion promoter. ${ }^{10} \mathrm{hAPP}$ Swedish mutation and $\mathrm{hPS} 1$ with the A246E mutation both under the mouse prion promoter. ${ }^{11} \mathrm{Tg} 2576$ (hAPP Swedish mutation) crossed with hPS1 with the M146L mutation. ${ }^{12} \mathrm{hTau}$ with the P301L mutation under the mouse prion promoter. A $\beta$, amyloid-beta; AD, Alzheimer's disease; APP, amyloid precursor protein; CAA, cerebral amyloid angiopathy; GFAP, glial fibrillary acidic protein; GFP, green Fluorescent Protein; IBA, ionized calcium binding adaptor molecule-1; IDE, insulin degrading enzyme; IFN, interferon; IL, interleukin; iNOS, inducible nitric oxide synthase; LTP, long-term potentiation; MyD88, myeloid differentiation primary response protein 88; NSE-COX2, neuron-specific enolase-cyclooxigenase2; PDAPP, amyloid precursor protein under control of platelet-derived growth factor promoter; PDGF, platelet-derived growth factor; PGE2, prostaglandin E2; PHF, Paired helical filament; PPAR, peroxisome proliferator-activated receptor; RAGE, Receptor for Advanced Glycation End; ROS, reactive oxygen species; Scar, scavenger receptor; Tg, transgenic; TGF, transforming growth factor; TLR, Toll-like receptor; TNF, tumor necrosis factor. 
to fibrillar forms of $A \beta$ [91]. Deletion of CD14, which acts as a co-receptor for LPS along with TLR2 and TLR4, in APP/PS1 mice reduced total microglial numbers, in particular CD45-positive microglia, attenuated AD pathology whilst also increasing the expression of TNF- $\alpha$ and IL-10, suggesting an induction of a shift of activation of microglia towards the M2b state [76]. On the other hand, TLR2 deficiency accelerated spatial and contextual memory impairments, which correlated with increased levels of $A \beta(1-42)$ and transforming growth factor- $\beta$ in the brain of APP/PS1 mice [87]. An essential adaptor protein for all TLR signaling, with the exception of TLR3, is the myeloid differentiation primary response protein 88 (MyD88). Decreasing the expression of MyD88 in APP/PS1 mice led to exacerbation of spatial memory deficits, increases in $A \beta$, reduced expression of the fractalkine receptor CX3CR1 and increased levels of APOE (Apolipoprotein E) together with reduced astrocyte and microglial activation [85,86]. These data indicate that TLR2 and TLR4 may be involved in $\mathrm{A} \beta$ clearance in vivo and hence provide neuroprotection in $\mathrm{AD}$ [92]. They also suggest that targeting specific glial activation states may prove fruitful in future clinical studies.

CD33 gene and TREM2, which are expressed in microglia, have been recently identified as genetic risks factors for $\mathrm{AD}$ [93-96]. It was reported that CD33 is able to inhibit the uptake and clearance of $A \beta 42$ in microglial cell cultures. This was confirmed by in vivo results showing that brain levels of insoluble $\mathrm{A} \beta 42$ as well as amyloid plaque burden were markedly reduced in APP(Swe)/PS1 $(\triangle \mathrm{E} 9) / \mathrm{CD} 33(-/-)$ mice. Therefore, CD33 inactivation appears to mitigate $A \beta$ pathology [77]. On the other hand, hypothesizing that the TREM2 risk variants impair TREM2 function, these new genetic studies suggest that reduced function of TREM2 causes reduced phagocytic clearance of amyloid proteins or cellular debris and thus impairs a protective mechanism in the brain $[94,96]$.

There are a number of studies that attribute the clearance of amyloid in mouse models to infiltrating monocytes or perivascular macrophages [97-100]. This is due to the evidence showing a reduced efficiency of microglia with age [101] and bacterial and viral infections [102]. However, the role of these peripheral monocytes in neurodegeneration remains unclear. One important aspect is the contribution of monocytes to resident macrophages, which is highly tissue-dependent and has been shown not to be relevant for brain microglia. However, recently it was suggested that, irrespective of their origin, macrophages/microglia can self-renew by local proliferation similar to that of stem cells [103]. In fact, in animal models of prion disease it has been demonstrated that microglial proliferation is a major component in the evolution of chronic neurodegeneration [104].
Many models that show peripheral monocytic infiltration use whole body irradiation which damages the blood-brain barrier itself, induces peripheral immune activation and can facilitate infiltration. Using this approach, it was recently published that microglia-depleted brain regions of CD11b-TK transgenic mice are repopulated with new Iba1-positive cells within 2 weeks, creating a niche for myeloid cells [105]. However, using the technique of parabiosis (in which two mice share vasculature), GFP (Green Fluorescent Protein) -labelled monocytes from one mouse are not seen to infiltrate the brain of the other mouse, except following irradiation and bone marrow transplantation, which would suggest a pre-existing disease state is necessary in the brain for significant infiltration to occur $[102,106]$. In line with this, recent data provide strong evidence that the engraftment of myeloid cells in the brain parenchyma of AD transgenic mice does not occur normally during disease progression, but requires prior central nervous system conditioning to sufficiently attract bone marrow cells [102]. These studies also highlight the importance of the chemokine receptor CCR2 in monocyte migration as the infiltrating cells following irradiation are characterized as $\mathrm{CCR} 2^{+}$. Interestingly, deletion of CCR2 in $\operatorname{Tg} 2576$ mice increased A $\beta$ accumulation and reduced microglial recruitment into the brain, in particular phagocytic macrophages [67]. In agreement with this, another study showed that restriction of CCR2 deficiency to perivascular myeloid cells drastically impaired $A \beta$ clearance and amplified vascular $A \beta$ deposition, while parenchymal plaque deposition remained unaffected [102].

Furthermore, inflammatory IFN $\gamma$-secreting Th1 cells and IL-17-secreting Th17 cells have been shown to infiltrate the brain of older APP/PS1 mice [107], supporting the observation of infiltrating $\mathrm{T}$ cells in the brain of $\mathrm{AD}$ patients [108]. However, the role of these cells in the AD brain is still unknown.

\section{Manipulation of astrocytes in animal models of Alzheimer's disease}

Astrocytes are becoming increasingly recognized as having key immune functions in the brain, and their role in Alzheimer's disease progression has recently been investigated. Whilst currently falling behind the number of studies that are published assessing microglial function in $\mathrm{AD}$, it is clear that astrocytes have a significant role to play in $\mathrm{AD}$ and therefore warrant significant future research.

Attenuation of astrocytic activation via deletion of GFAP and vimentin in APP/PS1 mice exacerbated amyloid plaque load independent of APP processing and A $\beta$ production [89], suggesting that astrocytes are important in amyloid clearance. Yet a previous study has shown that blocking astrocyte activation via AAV-Gfa2 vectors 
in APP/PS1 mice also attenuates microglia activation, improves cognitive and synaptic function and reduces amyloid load [109]. However these mice were analyzed at a considerably older age (16 to 18 months) when compared with the more recent study (8 to 12 months) which suggests that there may be a significant timing factor involved in targeting the immune response in AD.

Whether astrocytes are promoting amyloid clearance or exacerbating deposition is in debate; $\alpha_{1}$-antichymotrypsin $\left(\alpha_{1}-\mathrm{ACT}\right)$, an acute-phase protein that is overexpressed by activated astrocytes surrounding the amyloid plaques in human $\mathrm{AD}$ brains, has been proven to promote $\mathrm{A} \beta$ fibrillization. Confirming this, overexpression of a human transgene by astrocytes in the PDGF-APP ${ }_{\text {SweInd }}$ J9 or PDAPP mouse model promoted $\mathrm{A} \beta$ deposition and plaque formation [36,37]. It also affected tau phosphorylation and p-tau was increased both in single transgenic GFAP- $\alpha_{1}$ ACT and in APP-GFAP- $\alpha_{1}$-ACT mice [38].

\section{Anti-inflammatory therapy}

\section{Non-steroidal anti-inflammatory drugs}

Many inflammatory pathways have been implicated in $\mathrm{AD}$, yet these pathways are not sufficiently well delineated to define those processes and targets that may be pathogenic as opposed to those that may be protective. The finding that treatment with non-steroidal antiinflammatory drugs (NSAIDs) is associated with a reduced risk and age of onset of $\mathrm{AD}$ reinforces the hypothesis that modulating inflammation could have therapeutic efficacy. The beneficial effects of NSAIDs have also been associated with reductions in $A \beta$ generation, since experiments in vitro and in AD models indicate that certain NSAIDs are able to decrease $A \beta$ levels, plaque size and tau phosphorylation $[110,111]$.

The mechanism by which NSAIDs are protective has yielded controversial results. The initial hypothesis was that NSAIDs may affect A $\beta$ aggregation [112,113]. Following this, it was suggested that a subset of NSAIDs was affecting the $\gamma$-secretase cleavage site and the ratio A $340 / 42[114,115]$. Some recent studies have shown that treatment of AD mice with a novel NSAID derivative, CHF5074, which has a more selective action on $\gamma$ secretase, resulted in modulation of $\mathrm{A} \beta 42$ production without affecting C-terminal APP or Notch processing [116-118]. Chronic treatment in Tg2576 mice ameliorated memory deficits and loss of dendritic spine density together with a reduction in $\mathrm{A} \beta$ load, activated microglia and neuronal cell death [119]. Another potential target of NSAIDs is COX-1 [120]. It was recently reported that treatment of $3 \times \mathrm{Tg}-\mathrm{AD}$ mice with the $\mathrm{COX}-1$ selective inhibitor SC-560 improved spatial learning and memory, and reduced amyloid deposits and tau hyperphosphorylation. SC-560 also reduced glial activation and brain expression of inflammatory markers [121]. Certain NSAIDs are also agonists for peroxisome proliferator-activated receptor (PPAR) $\gamma$ and have been shown to reduce BACE1 $[22,122]$. However, PPAR $\gamma$ activation can affect the transcription of other proteins involved in $\mathrm{AD}$ as well (see section below).

However, clinical trials have failed to reproduce the beneficial effects of NSAIDs in AD patients. The success of NSAIDs clinically is likely to be dependent on the stage of the disease at which the medication is started as well as the duration of the treatment [111], since their benefit seems to be towards a preventive effect rather than a therapeutic option. Interestingly, clinical trials with anti-inflammatory drugs such as trifusal in MCI (mild cognitive impairment) patients have shown a significant lower rate of conversion to dementia that is likely to be clinically relevant [123].

\section{Peroxisome proliferator-activated receptor- $\gamma$ agonists}

PPAR $\gamma$ is a nuclear receptor that regulates the transcription of pro-inflammatory genes, such as IL1 $\beta$ and iNOS. Activation of PPAR $\gamma$ is therefore able to inhibit the inflammatory response, and acute and chronic treatment with the PPAR $\gamma$ agonist pioglitazone in APPV717I and Tg2576 mice resulted in a reduction in the number of activated microglia [122,124]. In addition, our group found that PPAR $\gamma$ activators decrease total $A \beta$ levels under inflammatory conditions by affecting BACE1 transcription $[6,22,23]$. On the other hand, it was shown in neuronal cells that ibuprofen is able to suppress RhoA activity through PPAR $\gamma$ activation, promoting neurite elongation [125]. Therefore PPAR $\gamma$ activation could be beneficial in AD at several levels.

Other groups have suggested that PPAR $\gamma$ may affect $A \beta$ clearance and degradation. It was recently demonstrated that PPAR $\gamma$ activation induces $l x r \alpha$, apoe, and abcal expression, promoting $A \beta$ clearance by both microglia and astrocytes [126]. Furthermore, PPAR $\gamma$ can stimulate A $\beta$ phagocytosis by the upregulation of scavenger receptor CD36 expression. It has also been shown that combined treatment with agonists for the heterodimeric binding partners of PPAR $\gamma$, the retinoid X receptors (RXRs), showed additive enhancement of the $A \beta$ uptake that was mediated by RXR $\alpha$ activation [127].

Treatment with PPAR agonists has also shown benefits in tau models. Treatment with the pan-PPAR agonist bezafibrate significantly decreased tau hyperphosphorylation and caused behavioural improvement, as evidenced by reduced hyperactivity and disinhibition in P301S mice [128]. In addition, $3 \times \mathrm{Tg}-\mathrm{AD}$ mice treated with pioglitazone for 4 months showed improved learning, decreased hippocampal $A \beta$ and tau deposits, and enhanced short- and longterm plasticity [129].

Clinical trials with PPAR $\gamma$ activators have been more successful than those with NSAIDs. A randomised study 
with pioglitazone (a typical PPAR $\gamma$ agonist) showed significantly increased memory scores in treated patients [130]. Another PPAR $\gamma$ agonist, rosiglitazone, has been trialled with inconsistent results, due to its lack of permeability in the brain and its differential effects depending on the APOE (Apolipoprotein E) \&4 genotype [131].

\section{Minocycline}

Minocycline, a tetracycline derivative, has potent antiinflammatory, anti-apoptotic, and neuroprotective properties. In many cases, the neuroprotective properties of minocycline have been attributed to inhibition of caspases. In primary cortical neurons, minocycline was shown to reduce caspase- 3 activation and lowered generation of caspase 3-cleaved tau fragments [132]. Recently, minocycline was shown to protect against $A \beta$-induced cell death and prevent fibrillization of $A \beta$ in vitro [133], reduce iNOS levels [134], prevent $A \beta$ deposition and cognitive decline in APP transgenic mice $[134,135]$ by reducing BACE1 levels [134], inhibit neuronal death and attenuate learning and memory deficits following administration of $A \beta$ in rats $[136,137]$. In addition, treatment of a tau model with minocycline resulted in reduced levels of tau phosphorylation and insoluble tau aggregates [132].

Another potential mechanism of action of minocycline has been related to the inhibition of microglial activation. Administration of minocycline in animal models of ALS attenuated the induction of the expression of M1 microglia markers during the progressive phase, whereas it did not affect the transient enhancement of expression of M2 microglia markers during the early pathogenesis phase [138]. This study suggests that minocycline may selectively inhibit the microglia polarisation to a proinflammatory state.

\section{Anti-TNFa}

TNF $\alpha$ is upregulated in AD and it has been found to increase in a stage-specific manner in the $\mathrm{APP}_{\mathrm{SWE}} / \mathrm{PS} 1 \mathrm{dE} 9$ mouse model [139]. Interestingly, anti-TNF $\alpha$ treatment with the antibody against TNF $\alpha$, infliximab, reduced $A \beta$ and tau phosphorylation in transgenic mice. In addition, infliximab increased the number of CD11c-positive dendritic-like cells and the expression of CD11c, suggesting that the CD11c-positive dendritic-like cells might contribute to the infliximab-induced reduction of $\mathrm{AD}$-like pathology [140].

The TNF $\alpha$ inhibitor thalidomide has been found to have abilities against tumour growth, angiogenesis, and inflammation. Chronic administration of thalidomide in APP23 and $3 \times \mathrm{Tg}-\mathrm{AD}$ mice resulted in a dramatic decrease in the activation of both astrocytes and microglia, A $\beta$ load, plaque formation and tau phosphorylation $[141,142]$. Furthermore, a significant decrease in BACE1 level and activity was also found [141]. However, it is not expected that this type of treatment will be beneficial for tau pathology, according to the results published in TNFRI knockout mice.

\section{Conclusions}

The advances in $\mathrm{AD}$ research in the last decade have brought to light that this disease is multi-faceted in nature and is linked to a variety of different functional mechanisms in the brain. That inflammatory processes play a role in $\mathrm{AD}$ cannot be disputed, and yet there are still many unanswered questions as to whether this is beneficial or detrimental.

The use of genetic and drug manipulation in transgenic $\mathrm{AD}$ mice have provided in vivo support to previous in vitro observations regarding the potential effects of inflammation on the processing of APP and the phosphorylation of tau. In this regard, enhancing inflammation has been linked with increases in $A \beta$ generation, $A \beta$ aggregation and tau phosphorylation. While, at first glance, data obtained in the transgenic models might suggest differential effects of immune modulation on APP and tau models, the very few studies undertaken and reported here do seem to follow a similar hypothesis that a general enhancement of immune activation in the brain increases pathology but that targeted activation of factors promoting phagocytosis and clearance of amyloid may also reduce the hyperphosphorylation of tau. On the other hand, modulation of inflammation in the $3 \times \mathrm{Tg}$ - $\mathrm{AD}$ model has suggested that the alterations on tau phosphorylation can be independent of changes in $A \beta$ levels by these inflammatory mediators.

Preclinical investigations on anti-inflammatory treatments have shown that certain drugs target these effects and potentially decrease BACE1 transcription (such as TNF $\alpha$ inhibitors and PPAR $\gamma$ activators) and increase $A \beta$ degradation. Current research strongly suggests that targeting specific microglial phenotypes as opposed to inflammation in general will yield more promising therapeutic results. This is important in light of the different phenotypic microglial activation in different stages of the disease. Harnessing the ability of microglia to efficiently clear $A \beta$ has significant therapeutic potential. In addition, utilising the phagocytic capabilities of infiltrating macrophages to clear $A \beta$, in particular targeting CCR2 in specific myeloid lineages, would be of substantial benefit. It is also worth noting that the promising effects of anti-inflammatory drugs are possibly preventive treatments and are not aimed at curing the disease.

The studies presented here also highlight the dangers of translating observations in animal studies into human studies and clinical trials. Currently available models do not accurately and fully reflect AD in humans; however, they are particularly useful at testing and predicting how certain manipulations will affect amyloid or tau deposition 
more specifically rather than overall disease progression. This makes it very clear that testing any potential therapies must be undertaken in a range of $\mathrm{AD}$ models to fully elucidate the predicted outcome in humans. Further studies assessing the potential for targeting these specific inflammatory processes, in addition to the role of astrocytes and infiltrating macrophages, are needed to elucidate more effective treatments and provide a clearer understanding of the complexities of inflammatory signalling in $\mathrm{AD}$.

\section{Abbreviations \\ $a_{1}-A C T$ : $a_{1}$-antichymotrypsin; $A B$ : Amyloid-beta; AD: Alzheimer's disease; APP: Amyloid precursor protein; COX: Cyclooxygenase; IFN: Interferon; IL: Interleukin; iNOS: Inducible nitric oxide synthase; LPS: Lipopolysaccharide; MyD88: Myeloid differentiation primary response protein 88; NOS: Nitric oxide synthase; NSAID: Non-steroidal anti-inflammatory drug; PPAR: Peroxisome proliferator-activated receptor; RXR: Retinoid X receptor; Scar: Scavenger receptor; Tg: Transgenic; TLR: Toll-like receptors; TNF: Tumor} necrosis factor; TSPO: Translocator protein.

\section{Competing interests}

The authors declare that they have no competing interests.

\section{Authors' contributions}

AMB and MS contributed equally to drafting the main text, and LK produced the tables and references. All authors read and approved the final manuscript.

\section{Acknowledgements}

The authors would like to thank Professor Steve Gentleman for critical reading of the manuscript.

Received: 26 November 2013 Accepted: 21 January 2014

Published: 3 February 2014

\section{References}

1. Blasko I, Stampfer-Kountchev M, Robatscher P, Veerhuis R, Eikelenboom P, Grubeck-Loebenstein B: How chronic inflammation can affect the brain and support the development of Alzheimer's disease in old age: the role of microglia and astrocytes. Aging Cell 2004, 3:169-176.

2. Sastre M, Klockgether T, Heneka MT: Contribution of inflammatory processes to Alzheimer's disease: molecular mechanisms. Int J Dev Neurosci 2006, 24:167-176.

3. Benzing WC, Wujek JR, Ward EK, Shaffer D, Ashe KH, Younkin SG, Brunden KR: Evidence for glial-mediated inflammation in aged APPSW transgenic mice. Neurobiol Aging 1999, 20:581-589.

4. Bornemann KD, Wiederhold KH, Pauli C, Ermini F, Stalder M, Schnell L, Sommer B, Jucker M, Staufenbiel M: Abeta-induced inflammatory processes in microglia cells of APP23 transgenic mice. Am J Pathol 2001, 158:63-73.

5. Abbas N, Bednar I, Mix E, Marie S, Paterson D, Ljungberg A, Morris C, Winblad B, Nordberg A, Zhu J: Up-regulation of the inflammatory cytokines IFN-y and IL-12 and down-regulation of IL-4 in cerebral cortex regions of APPSWE transgenic mice. J Neuroimmunol 2002, 126:50-57.

6. Heneka MT, Sastre M, Dumitrescu-Ozimek L, Dewachter I, Walter J, Klockgether T, Van Leuven F: Focal glial activation coincides with increased BACE1 activation and precedes amyloid plaque deposition in APP[V717l] transgenic mice. J Neuroinflammation 2005, 2:22

7. Moechars D, Dewachter I, Lorent K, Reversé D, Baekelandt V, Naidu A, Tesseur I, Spittaels K, Haute CV, Checler F, Godaux E, Cordell B, Van Leuven $F$ : Early phenotypic changes in transgenic mice that overexpress different mutants of amyloid precursor protein in brain. J Biol Chem 1999, 274:6483-6492.

8. Oddo S, Caccamo A, Shepherd JD, Murphy MP, Golde TE, Kayed R, Metherate R, Mattson MP, Akbari Y, LaFerla FM: Triple-transgenic model of Alzheimer's disease with plaques and tangles: intracellular Abeta and synaptic dysfunction. Neuron 2003, 39:409-421.
9. Janelsins MC, Mastrangelo MA, Oddo S, LaFerla FM, Federoff HJ, Bowers WJ: Early correlation of microglial activation with enhanced tumor necrosis factor-alpha and monocyte chemoattractant protein-1 expression specifically within the entorhinal cortex of triple transgenic Alzheimer's disease mice. J Neuroinflammation 2005, 2:23.

10. Bellucci A, Westwood AJ, Ingram E, Casamenti F, Goedert M, Spillantini MG Induction of inflammatory mediators and microglial activation in mice transgenic for mutant human P301S tau protein. Am J Pathol 2004, 165:1643-1652.

11. Yoshiyama Y, Higuchi M, Zhang B, Huang SM, Iwata N, Saido TC, Maeda J, Suhara T, Trojanowski JQ, Lee VM: Synapse loss and microglial activation precede tangles in a P301S tauopathy mouse model. Neuron 2007, 53:337-351.

12. Cohen RM, Rezai-Zadeh K, Weitz TM, Rentsendorj A, Gate D, Spivak I, Bholat Y, Vasilevko V, Glabe CG, Breunig JJ, Rakic P, Davtyan H, Agadjanyan MG, Kepe V, Barrio JR, Bannykh S, Szekely CA, Pechnick RN, Town T: A transgenic Alzheimer rat with plaques, tau pathology, behavioral impairment, oligomeric abeta, and frank neuronal loss. J Neurosci 2013, 33:6245-6256.

13. Roberts JC, Friel SL, Roman S, Perren M, Harper A, Davis JB, Richardson JC, Virley D, Medhurst AD: Autoradiographical imaging of PPARgamma agonist effects on PBR/TSPO binding in TASTPM mice. Exp Neurol 2009, 216:459-470.

14. Rapic $\mathrm{S}$, Backes $\mathrm{H}$, Viel T, Kummer MP, Monfared P, Neumaier B, Vollmar $\mathrm{S}$, Hoehn M, Van der Linden A, Heneka MT, Jacobs AH: Imaging microglial activation and glucose consumption in a mouse model of Alzheimer's disease. Neurobiol Aging 2013, 34:351-354

15. Holland JP, Liang SH, Rotstein BH, Collier TL, Stephenson NA, Greguric I, Vasdev N: Alternative approaches for PET radiotracer development in Alzheimer's disease: imaging beyond plaque. I Labelled Comp Radiopharm 2013. In press.

16. Maeda J, Zhang MR, Okauchi T, Ji B, Ono M, Hattori S, Kumata K, Iwata N, Saido TC, Trojanowski JQ, Lee VM, Staufenbiel M, Tomiyama T, Mori H, Fukumura T, Suhara T, Higuchi M: In vivo positron emission tomographic imaging of glial responses to amyloid-beta and tau pathologies in mouse models of Alzheimer's disease and related disorders. J Neurosci 2011, 31:4720-4730.

17. Colton CA, Vitek MP, Wink DA, Xu Q, Cantillana V, Previti ML, Van Nostrand WE, Weinberg JB, Dawson H: NO synthase 2 (NOS2) deletion promotes multiple pathologies in a mouse model of Alzheimer's disease. Proc Nat Acad Sci USA 2006, 103:12867-12872.

18. Kummer MP, Hermes M, Delekarte A, Hammerschmidt T, Kumar S, Terwel D, Walter J, Pape HC, Konig S, Roeber S, Jessen F, Klockgether T, Korte M, Heneka MT: Nitration of tyrosine 10 critically enhances amyloid beta aggregation and plaque formation. Neuron 2011, 71:833-844.

19. Vom Berg J, Prokop S, Miller KR, Obst J, Kalin RE, Lopategui-Cabezas I, Wegner A, Mair F, Schipke CG, Peters O, Winter Y, Becher B, Heppner FL: Inhibition of IL-12/L-23 signaling reduces Alzheimer's disease-like pathology and cognitive decline. Nat Med 2012, 18:1812-1819.

20. Yamamoto M, Kiyota T, Horiba M, Buescher JL, Walsh SM, Gendelman HE, Ikezu T: Interferon-gamma and tumor necrosis factor-alpha regulate amyloid-beta plaque deposition and beta-secretase expression in Swedish mutant APP transgenic mice. Am J Pathol 2007, 170:680-692.

21. He P, Zhong Z, Lindholm K, Berning L, Lee W, Lemere C, Staufenbiel M, Li R, Shen $Y$ : Deletion of tumor necrosis factor death receptor inhibits amyloid beta generation and prevents learning and memory deficits in Alzheimer's mice. J Cell Biol 2007, 178:829-841.

22. Sastre M, Dewachter I, Landreth GE, Willson TM, Klockgether T, van Leuven F, Heneka MT: Nonsteroidal anti-inflammatory drugs and peroxisome proliferator-activated receptor-gamma agonists modulate immunostimulated processing of amyloid precursor protein through regulation of beta-secretase. J Neurosci 2003, 23:9796-9804.

23. Sastre $M$, Dewachter I, Rossner $S$, Bogdanovic N, Rosen E, Borghgraef $P$, Evert BO, Dumitrescu-Ozimek L, Thal DR, Landreth G, Walter J, Klockgether $T$, van Leuven F, Heneka MT: Nonsteroidal anti-inflammatory drugs repress beta-secretase gene promoter activity by the activation of PPARgamma. Proc Natl Acad Sci USA 2006, 103:443-448.

24. Montgomery SL, Mastrangelo MA, Habib D, Narrow WC, Knowlden SA, Wright TW, Bowers WJ: Ablation of TNF-RI/RII expression in Alzheimer's disease mice leads to an unexpected enhancement of pathology: implications for chronic pan-TNF-alpha suppressive therapeutic strategies in the brain. Am J Pathol 2011, 179:2053-2070. 
25. Giuliani F, Vernay A, Leuba G, Schenk F: Decreased behavioral impairments in an Alzheimer mice model by interfering with TNF-alpha metabolism. Brain Res Bull 2009, 80:302-308.

26. Ghosh S, Wu MD, Shaftel SS, Kyrkanides S, LaFerla FM, Olschowka JA, O'Banion MK: Sustained interleukin-1 beta overexpression exacerbates tau pathology despite reduced amyloid burden in an Alzheimer's mouse model. J Neurosci 2013, 33:5053-5064.

27. Shaftel SS, Kyrkanides S, Olschowka JA, Miller JN, Johnson RE, O'Banion MK: Sustained hippocampal IL-1 beta overexpression mediates chronic neuroinflammation and ameliorates Alzheimer plaque pathology. J Clin Invest 2007, 117:1595-1604

28. Matousek SB, Ghosh S, Shaftel SS, Kyrkanides S, Olschowka JA, O'Banion MK: Chronic IL-1beta-mediated neuroinflammation mitigates amyloid pathology in a mouse model of Alzheimer's disease without inducing overt neurodegeneration. J Neuroim Pharmacol 2012, 7:156-164.

29. Wyss-Coray T, Lin C, Yan F, Yu GQ, Rohde M, McConlogue L, Masliah E, Mucke L: TGF-beta1 promotes microglial amyloid-beta clearance and reduces plaque burden in transgenic mice. Nat Med 2001, 7:612-618.

30. Wyss-Coray T, Masliah E, Mallory M, McConlogue L, Johnson-Wood K, Lin C, Mucke L: Amyloidogenic role of cytokine TGF-beta1 in transgenic mice and in Alzheimer's disease. Nature 1997, 389:603-606.

31. Town T, Laouar Y, Pittenger C, Mori T, Szekely CA, Tan J, Duman RS, Flavell RA: Blocking TGF-beta-Smad2/3 innate immune signaling mitigates Alzheimer-like pathology. Nat Med 2008, 14:681-687.

32. Kummer MP, Vogl T, Axt D, Griep A, Vieira-Saecker A, Jessen F, Gelpi E, Roth J, Heneka MT: Mrp14 deficiency ameliorates amyloid $\beta$ burden by increasing microglial phagocytosis and modulation of amyloid precursor protein processing. J Neurosci 2012, 32:17824-17829.

33. Kummer MP, Hulsmann C, Hermes M, Axt D, Heneka MT: Nitric oxide decreases the enzymatic activity of insulin degrading enzyme in APP/PS1 mice. J Neuroim Pharmacol 2012, 7:165-172.

34. Wilcock DM, Lewis MR, Van Nostrand WE, Davis J, Previti ML, Gharkholonarehe N, Vitek MP, Colton CA: Progression of amyloid pathology to Alzheimer's disease pathology in an amyloid precursor protein transgenic mouse model by removal of nitric oxide synthase 2 . J Neurosci 2008, 28:1537-1545.

35. Arancio O, Zhang HP, Chen X, Lin C, Trinchese F, Puzzo D, Liu S, Hegde A, Yan SF, Stern A, Luddy JS, Lue LF, Walker DG, Roher A, Buttini M, Mucke L, Li W, Schmidt AM, Kindy M, Hyslop PA, Stern DM, Du Yan SS: RAGE potentiates Abeta-induced perturbation of neuronal function in transgenic mice. EMBO J 2004, 23:4096-4105.

36. Mucke L, Yu GQ, McConlogue L, Rockenstein EM, Abraham CR, Masliah E: Astroglial expression of human alpha(1)-antichymotrypsin enhances alzheimer-like pathology in amyloid protein precursor transgenic mice. Am J Pathol 2000, 157:2003-2010.

37. Nilsson LN, Bales KR, DiCarlo G, Gordon MN, Morgan D, Paul SM, Potter H: Alpha-1-antichymotrypsin promotes beta-sheet amyloid plaque deposition in a transgenic mouse model of Alzheimer's disease. J Neurosci 2001, 21:1444-1451.

38. Padmanabhan J, Levy M, Dickson DW, Potter H: Alpha1-antichymotrypsin, an inflammatory protein overexpressed in Alzheimer's disease brain, induces tau phosphorylation in neurons. Brain 2006, 129:3020-3034.

39. Heneka MT, Kummer MP, Stutz A, Delekate A, Schwartz S, Vieira-Saecker A, Griep A, Axt D, Remus A, Tzeng TC, Gelpi E, Halle A, Korte M, Latz E, Golenbock DT: NLRP3 is activated in Alzheimer's disease and contributes to pathology in APP/PS1 mice. Nature 2013, 493:674-678.

40. Jaeger LB, Dohgu S, Sultana R, Lynch JL, Owen JB, Erickson MA, Shah GN, Price TO, Fleegal-Demotta MA, Butterfield DA, Banks WA: Lipopolysaccharide alters the blood-brain barrier transport of amyloid beta protein: a mechanism for inflammation in the progression of Alzheimer's disease. Brain Behav Immun 2009, 23:507-517.

41. Herber DL, Roth LM, Wilson D, Wilson N, Mason JE, Morgan D, Gordon MN: Time-dependent reduction in Abeta levels after intracranial LPS administration in APP transgenic mice. Exp Neurol 2004, 190:245-253.

42. Herber DL, Mercer M, Roth LM, Symmonds K, Maloney J, Wilson N, Freeman MJ, Morgan D, Gordon MN: Microglial activation is required for Abeta clearance after intracranial injection of lipopolysaccharide in APP transgenic mice. J Neuroim Pharmacol 2007, 2:222-231.

43. Barrientos RM, Higgins EA, Sprunger DB, Watkins LR, Rudy JW, Maier SF: Memory for context is impaired by a post context exposure injection of interleukin-1 beta into dorsal hippocampus. Behav Brain Res 2002, 134:291-298.

44. Chen J, Buchanan JB, Sparkman NL, Godbout JP, Freund GG, Johnson RW: Neuroinflammation and disruption in working memory in aged mice after acute stimulation of the peripheral innate immune system. Brain Behav Immun 2008, 22:301-311.

45. Otth C, Concha II, Arendt T, Stieler J, Schliebs R, Gonzalez-Billault C, Maccioni RB: AbetaPP induces cdk5-dependent tau hyperphosphorylation in transgenic mice Tg2576. J Alzheimer dis 2002, 4:417-430.

46. Sturchler-Pierrat C, Abramowski D, Duke M, Wiederhold KH, Mistl C, Rothacher S, Ledermann B, Burki K, Frey P, Paganetti PA, Waridel C, Calhoun ME, Jucker M, Probst A, Staufenbiel M, Sommer B: Two amyloid precursor protein transgenic mouse models with Alzheimer disease-like pathology. Proc Natl Acad Sci USA 1997, 94:13287-13292.

47. Arnaud L, Robakis NK, Figueiredo-Pereira ME: It may take inflammation, phosphorylation and ubiquitination to 'tangle' in Alzheimer's disease. Neurodegener Dis 2006, 3:313-319.

48. Wyss-Coray T, Yan F, Lin AH, Lambris JD, Alexander JJ, Quigg RJ, Masliah E: Prominent neurodegeneration and increased plaque formation in complement-inhibited Alzheimer's mice. Proc Natl Acad Sci USA 2002, 99:10837-10842.

49. Britschgi M, Takeda-Uchimura Y, Rockenstein E, Johns H, Masliah E, Wyss-Coray T: Deficiency of terminal complement pathway inhibitor promotes neuronal tau pathology and degeneration in mice. J Neuroinflammation 2012, 9:220

50. Kitazawa M, Oddo S, Yamasaki TR, Green KN, LaFerla FM: Lipopolysaccharide-induced inflammation exacerbates tau pathology by a cyclin-dependent kinase 5-mediated pathway in a transgenic model of Alzheimer's disease. J Neurosci 2005, 25:8843-8853.

51. Sy M, Kitazawa M, Medeiros R, Whitman L, Cheng D, Lane TE, Laferla FM: Inflammation induced by infection potentiates tau pathological features in transgenic mice. Am J Pathol 2011, 178:2811-2822.

52. Tran HT, LaFerla FM, Holtzman DM, Brody DL: Controlled cortical impact traumatic brain injury in 3xTg-AD mice causes acute intra-axonal amyloid-beta accumulation and independently accelerates the development of tau abnormalities. J Neurosci 2011, 31:9513-9525.

53. Mastrangelo MA, Sudol KL, Narrow WC, Bowers WJ: Interferon-\{gamma\} differentially affects Alzheimer's disease pathologies and induces neurogenesis in triple transgenic-AD mice. Am J Pathol 2009, 175:2076-2088.

54. Montgomery SL, Narrow WC, Mastrangelo MA, Olschowka JA, O'Banion MK Bowers WJ: Chronic neuron- and age-selective down-regulation of TNF receptor expression in triple-transgenic Alzheimer disease mice leads to significant modulation of amyloid- and Tau-related pathologies. Am J Pathol 2013, 182:2285-2297.

55. Grathwohl SA, Kalin RE, Bolmont T, Prokop S, Winkelmann G, Kaeser SA, Odenthal J, Radde R, Eldh T, Gandy S, Aguzzi A, Staufenbiel M, Mathews PM, Wolburg H, Heppner FL, Jucker M: Formation and maintenance of Alzheimer's disease beta-amyloid plaques in the absence of microglia. Nat Neuroscience 2009, 12:1361-1363.

56. Perry $\mathrm{VH}$, Teeling J: Microglia and macrophages of the central nervous system: the contribution of microglia priming and systemic inflammation to chronic neurodegeneration. Semin Immunopathol 2013, 35:601-612.

57. Lee DC, Rizer J, Hunt JB, Selenica ML, Gordon MN, Morgan D: Review: experimental manipulations of microglia in mouse models of Alzheimer's pathology: activation reduces amyloid but hastens tau pathology. Neuropathol Appl Neurobiol 2013, 39:69-85.

58. Prokop S, Miller KR, Heppner FL: Microglia actions in Alzheimer's disease. Acta Neuropathol 2013, 126:461-477.

59. Liu Z, Condello C, Schain A, Harb R, Grutzendler J: CX3CR1 in microglia regulates brain amyloid deposition through selective protofibrillar amyloid-beta phagocytosis. J Neurosci 2010, 30:17091-17101.

60. Lee S, Varvel NH, Konerth ME, Xu G, Cardona AE, Ransohoff RM, Lamb BT: CX3CR1 deficiency alters microglial activation and reduces beta-amyloid deposition in two Alzheimer's disease mouse models. American J Pathol 2010, 177:2549-2562.

61. Fuhrmann M, Bittner $T$, Jung CK, Burgold S, Page RM, Mitteregger G, Haass C LaFerla FM, Kretzschmar H, Herms J: Microglial Cx3cr1 knockout prevents neuron loss in a mouse model of Alzheimer's disease. Nat Neuroscience 2010, 13:411-413. 
62. Cho SH, Sun B, Zhou Y, Kauppinen TM, Halabisky B, Wes P, Ransohoff RM, Gan L: CX3CR1 protein signaling modulates microglial activation and protects against plaque-independent cognitive deficits in a mouse model of Alzheimer disease. J Biol Chem 2011, 286:32713-32722.

63. Cardona AE, Pioro EP, Sasse ME, Kostenko V, Cardona SM, Dijkstra IM, Huang D, Kidd G, Dombrowski S, Dutta R, Lee JC, Cook DN, Jung S, Lira SA, Littman DR, Ransohoff RM: Control of microglial neurotoxicity by the fractalkine receptor. Nat Neuroscience 2006, 9:917-924.

64. Frenkel D, Wilkinson K, Zhao L, Hickman SE, Means TK, Puckett L, Farfara D, Kingery ND, Weiner HL, El Khoury J: Scara1 deficiency impairs clearance of soluble amyloid-beta by mononuclear phagocytes and accelerates Alzheimer's-like disease progression. Nat Comm 2030, 2013:4.

65. Thanopoulou K, Fragkouli A, Stylianopoulou F, Georgopoulos S: Scavenger receptor class $B$ type I (SR-BI) regulates perivascular macrophages and modifies amyloid pathology in an Alzheimer mouse model. Proc Natl Acad Sci USA 2010, 107:20816-20821.

66. Bhaskar K, Konerth M, Kokiko-Cochran ON, Cardona A, Ransohoff RM, Lamb BT: Regulation of tau pathology by the microglial fractalkine receptor. Neuron 2010, 68:19-31.

67. El Khoury J, Toft M, Hickman SE, Means TK, Terada K, Geula C, Luster AD: Ccr2 deficiency impairs microglial accumulation and accelerates progression of Alzheimer-like disease. Nat Med 2007, 13:432-438.

68. Naert G, Rivest S: CC chemokine receptor 2 deficiency aggravates cognitive impairments and amyloid pathology in a transgenic mouse model of Alzheimer's disease. J Neurosci 2011, 31:6208-6220.

69. Xiang Z, Ho L, Yemul S, Zhao Z, Qing W, Pompl P, Kelley K, Dang A, Qing W, Teplow D, Pasinetti GM: Cyclooxygenase-2 promotes amyloid plaque deposition in a mouse model of Alzheimer's disease neuropathology. Gene Expr 2002, 10:271-278.

70. Wyss-Coray T, Mucke L: Inflammation in neurodegenerative disease - a double-edged sword. Neuron 2002, 35:419-432.

71. Fonseca Ml, Zhou J, Botto M, Tenner AJ: Absence of C1q leads to less neuropathology in transgenic mouse models of Alzheimer's disease. J Neurosci 2004, 24:6457-6465.

72. Tan J, Town T, Paris D, Mori T, Suo Z, Crawford F, Mattson MP, Flavell RA, Mullan M: Microglial activation resulting from CD40-CD40L interaction after beta-amyloid stimulation. Science 1999, 286:2352-2355.

73. Laporte V, Ait-Ghezala G, Volmar CH, Mullan M: CD40 deficiency mitigates Alzheimer's disease pathology in transgenic mouse models. J Neuroinflammation 2006, 3:3.

74. Tan J, Town T, Crawford F, Mori T, DelleDonne A, Crescentini R, Obregon D, Flavell RA, Mullan MJ: Role of CD40 ligand in amyloidosis in transgenic Alzheimer's mice. Nat Neurosci 2002, 5:1288-1293.

75. Maier M, Peng Y, Jiang L, Seabrook TJ, Carroll MC, Lemere CA: Complement C3 deficiency leads to accelerated amyloid beta plaque deposition and neurodegeneration and modulation of the microglia/macrophage phenotype in amyloid precursor protein transgenic mice. J Neurosci 2008, 28:6333-6341

76. Reed-Geaghan EG, Reed QW, Cramer PE, Landreth GE: Deletion of CD14 attenuates Alzheimer's disease pathology by influencing the brain's inflammatory milieu. J Neurosci 2010, 30:15369-15373.

77. Griciuc A, Serrano-Pozo A, Parrado AR, Lesinski AN, Asselin CN, Mullin K, Hooli B, Choi SH, Hyman BT, Tanzi RE: Alzheimer's disease risk gene CD33 inhibits microglial uptake of amyloid beta. Neuron 2013, 78:631-643.

78. Park L, Wang G, Zhou P, Zhou J, Pitstick R, Previti ML, Younkin L, Younkin SG, Van Nostrand WE, Cho S, Anrather J, Carlson GA, ladecola C: Scavenger receptor $\mathrm{CD} 36$ is essential for the cerebrovascular oxidative stress and neurovascular dysfunction induced by amyloid-beta. Proc Natl Acad Sci USA 2011, 108:5063-5068.

79. Park L, Zhou J, Zhou P, Pistick R, El Jamal S, Younkin L, Pierce J, Arreguin A, Anrather J, Younkin SG, Carlson GA, McEwen BS, ladecola C: Innate immunity receptor CD36 promotes cerebral amyloid angiopathy. Proc Natl Acad Sci USA 2013, 110:3089-3094.

80. Zhu Y, Hou H, Rezai-Zadeh K, Giunta B, Ruscin A, Gemma C, Jin J, Dragicevic N, Bradshaw P, Rasool S, Glabe CG, Ehrhart J, Bickford P, Mori T, Obregon D, Town T, Tan J: CD45 deficiency drives amyloid-beta peptide oligomers and neuronal loss in Alzheimer's disease mice. J Neurosci 2011, 31:1355-1365.

81. Cameron B, Tse W, Lamb R, Li X, Lamb BT, Landreth GE: Loss of interleukin receptor-associated kinase 4 signaling suppresses amyloid pathology and alters microglial phenotype in a mouse model of Alzheimer's disease. J Neurosci 2012, 32:15112-15123.
82. Tahara K, Kim HD, Jin JJ, Maxwell JA, Li L, Fukuchi K: Role of toll-like receptor signalling in Abeta uptake and clearance. Brain 2006, 129:3006-3019.

83. Jin JJ, Kim HD, Maxwell JA, Li L, Fukuchi K: Toll-like receptor 4-dependent upregulation of cytokines in a transgenic mouse model of Alzheimer's disease. J Neuroinflammation 2008, 5:23.

84. Song M, Jin J, Lim JE, Kou J, Pattanayak A, Rehman JA, Kim HD, Tahara K, Lalonde R, Fukuchi K: TLR4 mutation reduces microglial activation, increases Abeta deposits and exacerbates cognitive deficits in a mouse model of Alzheimer's disease. J Neuroinflammation 2011, 8:92.

85. Lim JE, Kou J, Song M, Pattanayak A, Jin J, Lalonde R, Fukuchi K: MyD88 deficiency ameliorates beta-amyloidosis in an animal model of Alzheimer's disease. Am J Pathol 2011, 179:1095-1103.

86. Michaud JP, Richard KL, Rivest S: MyD88-adaptor protein acts as a preventive mechanism for memory deficits in a mouse model of Alzheimer's disease. Mol Neurodegener 2011, 6:5.

87. Richard KL, Filali M, Prefontaine P, Rivest S: Toll-like receptor 2 acts as a natural innate immune receptor to clear amyloid beta 1-42 and delay the cognitive decline in a mouse model of Alzheimer's disease. J Neurosci 2008, 28:5784-5793.

88. Yamamoto M, Horiba M, Buescher JL, Huang D, Gendelman HE, Ransohoff RM, Ikezu T: Overexpression of monocyte chemotactic protein-1/CCL2 in $\beta$-amyloid precursor protein transgenic mice show accelerated diffuse $\beta$-amyloid deposition. Am J Pathol 2005, 166:1475-1485.

89. Kraft AW, Hu X, Yoon H, Yan P, Xiao Q, Wang Y, Gil SC, Brown J, Wilhelmsson U, Restivo JL, Cirrito JR, Holtzman DM, Kim J, Pekny M, Lee JM: Attenuating astrocyte activation accelerates plaque pathogenesis in APP/PS1 mice. FASEB J 2013, 27:187-198.

90. Akashi-Takamura S, Miyake K: Toll-like receptors (TLRs) and immune disorders. J Infect Chemother 2006, 12:233-240.

91. Reed-Geaghan EG, Savage JC, Hise AG, Landreth GE: CD14 and Toll-like receptors 2 and 4 are required for fibrillar $A \beta$-stimulated microglial activation. J Neuroscience 2009, 29:11982-11992.

92. Solito E, Sastre M: Microglia function in Alzheimer's disease. Front Pharmacol 2012, 3:14

93. Bertram L, Lange C, Mullin K, Parkinson M, Hsiao M, Hogan MF, Schjeide BM Hooli B, Divito J, lonita I, Jiang H, Laird N, Moscarillo T, Ohlsen KL, Elliott K, Wang X, Hu-Lince D, Ryder M, Murphy A, Wagner SL, Blacker D, Becker KD, Tanzi RE: Genome-wide association analysis reveals putative Alzheimer's disease susceptibility loci in addition to APOE. Am J Hum Genet 2008, 83:623-632

94. Guerreiro R, Wojtas A, Bras J, Carrasquillo M, Rogaeva E, Majounie E, Cruchaga C, Sassi C, Kauwe JS, Younkin S, Hazrati L, Collinge J, Pocock J, Lashley T, Williams J, Lambert JC, Amouyel P, Goate A, Rademakers R, Morgan K, Powell J, St George-Hyslop P, Singleton A, Hardy J, Alzheimer Genetic Analysis Group: TREM2 variants in Alzheimer's disease. N Engl J Med 2013, 368:117-127.

95. Hollingworth P, Sweet R, Sims R, Harold D, Russo G, Abraham R, Stretton A, Jones N, Gerrish A, Chapman J, Ivanov D, Moskvina V, Lovestone S, Priotsi P, Lupton M, Brayne C, Gill M, Lawlor B, Lynch A, Craig D, McGuinness B, Johnston J, Holmes C, Livingston G, Bass NJ, Gurling H, McQuillin A, GERAD Consortium, National Institute on Aging Late-Onset Alzheimer's Disease Family Study Group, Holmans P, Jones L, Devlin B, Klei L, Barmada MM, Demirci FY, DeKosky ST, Lopez OL, Passmore P, Owen MJ, O'Donovan MC, Mayeux R, Kamboh MI, Williams J: Genome-wide association study of Alzheimer's disease with psychotic symptoms. Mol Psychiatry 2012, 17:1316-1327

96. Jonsson T, Stefansson H, Steinberg S, Jonsdottir I, Jonsson PV, Snaedal J, Bjornsson S, Huttenlocher J, Levey Al, Lah JJ, Rujescu D, Hampel H, Giegling I, Andreassen OA, Engedal K, Ulstein I, Djurovic S, Ibrahim-Verbaas C, Hofman A, Ikram MA, van Duijn CM, Thorsteinsdottir U, Kong A, Stefansson K: Variant of TREM2 associated with the risk of Alzheimer's disease. N Engl J Med 2013, 368:107-116.

97. Hawkes CA, McLaurin J: Selective targeting of perivascular macrophages for clearance of beta-amyloid in cerebral amyloid angiopathy. Proc Natl Acad Sci USA 2009, 106:1261-1266.

98. Majumdar A, Chung H, Dolios G, Wang R, Asamoah N, Lobel P, Maxfield FR: Degradation of fibrillar forms of Alzheimer's amyloid beta-peptide by macrophages. Neurobiol Aging 2008, 29:707-715.

99. Malm TM, Koistinaho M, Parepalo M, Vatanen T, Ooka A, Karlsson S, Koistinaho J: Bone-marrow-derived cells contribute to the recruitment of 
microglial cells in response to beta-amyloid deposition in APP/PS1 double transgenic Alzheimer mice. Neurobiol Dis 2005, 18:134-142.

100. Simard AR, Rivest S: Bone marrow stem cells have the ability to populate the entire central nervous system into fully differentiated parenchymal microglia. FASEB J 2004, 18:998-1000.

101. Streit WJ: Microglial senescence: does the brain's immune system have an expiration date? Trends Neurosci 2006, 29:506-510.

102. Mildner A, Schlevogt B, Kierdorf K, Bottcher C, Erny D, Kummer MP, Quinn M, Bruck W, Bechmann I, Heneka MT, Priller J, Prinz M: Distinct and non-redundant roles of microglia and myeloid subsets in mouse models of Alzheimer's disease. J Neurosci 2011, 31:11159-11171.

103. Sieweke MH, Allen JE: Beyond stem cells: self-renewal of differentiated macrophages. Science 2013, 342:1242974.

104. Gomez-Nicola D, Fransen NL, Suzzi S, Perry VH: Regulation of microglial proliferation during chronic neurodegeneration. J Neurosci 2013, 33:2481-2493.

105. Varvel NH, Grathwohl SA, Baumann F, Liebig C, Bosch A, Brawek B, Thal DR Charo IF, Heppner FL, Aguzzi A, Garaschuk O, Ransohoff RM, Jucker M: Microglial repopulation model reveals a robust homeostatic process for replacing CNS myeloid cells. Proc Natl Acad Sci USA 2012, 109:18150-18155.

106. Ajami B, Bennett JL, Krieger C, Tetzlaff W, Rossi FM: Local self-renewal can sustain CNS microglia maintenance and function throughout adult life. Nat Neurosci 2007, 10:1538-1543.

107. Browne TC, McQuillan K, McManus RM, O'Reilly JA, Mills KH, Lynch MA: IFN-gamma production by amyloid beta-specific Th1 cells promotes microglial activation and increases plaque burden in a mouse model of Alzheimer's disease. J Immunol 2013, 190:2241-2251.

108. Rogers J, Luber-Narod J, Styren SD, Civin WH: Expression of immune system-associated antigens by cells of the human central nervous system: relationship to the pathology of Alzheimer's disease. Neurobio/ Aging 1988, 9:339-349.

109. Furman JL, Sama DM, Gant JC, Beckett TL, Murphy MP, Bachstetter AD, Van Eldik $L$, Norris CM: Targeting astrocytes ameliorates neurologic changes in a mouse model of Alzheimer's disease. J Neurosci 2012, 32:16129-16140.

110. El Khoury J, Luster AD: Mechanisms of microglia accumulation in Alzheimer's disease: therapeutic implications. Trends Pharmacol Sci 2008, 29:626-632

111. Sastre M, Gentleman SM: NSAIDs: how they work and their prospects as therapeutics in Alzheimer's disease. Front Aging Neurosci 2010, 2:20

112. Lim GP, Yang F, Chu T, Chen P, Beech W, Teter B, Tran T, Ubeda O, Ashe KH, Frautschy SA, Cole GM: Ibuprofen suppresses plaque pathology and inflammation in a mouse model for Alzheimer's disease. J Neurosci 2000, 20:5709-5714

113. Lim GP, Yang F, Chu T, Gahtan E, Ubeda O, Beech W, Overmier JB, Hsiao-Ashec K, Frautschy SA, Cole GM: Ibuprofen effects on Alzheimer pathology and open field activity in APPsw transgenic mice. Neurobio Aging 2001, 22:983-991.

114. Eriksen JL, Sagi SA, Smith TE, Weggen S, Das P, McLendon DC, Ozols W, Jessing KW, Zavitz KH, Koo EH, Golde TE: NSAIDs and enantiomers of flurbiprofen target gamma-secretase and lower Abeta 42 in vivo. J Clin Invest 2003, 112:440-449.

115. Weggen S, Eriksen JL, Das P, Sagi SA, Wang R, Pietrzik CU, Findlay KA, Smith TE, Murphy MP, Bulter T, Kang DE, Marquez-Sterling N, Golde TE, Koo EH: A subset of NSAIDs lower amyloidogenic Abeta42 independently of cyclooxygenase activity. Nature 2001, 414:212-216.

116. Imbimbo BP, Giardino L, Sivilia S, Giuliani A, Gusciglio M, Pietrini V, Del Giudice E, D'Arrigo A, Leon A, Villetti G, Calza L: CHF5074, a novel gamma-secretase modulator, restores hippocampal neurogenesis potential and reverses contextual memory deficit in a transgenic mouse model of Alzheimer's disease. J Alzheimer's dis 2010, 20:159-173.

117. Imbimbo BP, Del Giudice E, Cenacchi V, Volta R, Villetti G, Facchinetti F, Riccardi B, Puccini P, Moretto N, Grassi F, Ottonello S, Leon A: In vitro and in vivo profiling of CHF5022 and CHF5074 Two beta-amyloid1-42 lowering agents. Pharmacol Res 2007, 55:318-328.

118. Balducci C, Mehdawy B, Mare L, Giuliani A, Lorenzini L, Sivilia S, Giardino L, Calza L, Lanzillotta A, Sarnico I, Pizzi M, Usiello A, Viscomi AR, Ottonello S, Villetti G, Imbimbo BP, Nisticò G, Forloni G, Nisticò R: The gamma-secretase modulator CHF5074 restores memory and hippocampal synaptic plasticity in plaque-free Tg2576 mice. J Alzheimer's dis 2011, 24:799-816.
119. Sivilia S, Lorenzini L, Giuliani A, Gusciglio M, Fernandez M, Baldassarro VA, Mangano C, Ferraro L, Pietrini V, Baroc MF, Viscomi AR, Ottonello S, Villetti G, Imbimbo BP, Calzà L, Giardino L: Multi-target action of the novel anti-Alzheimer compound CHF5074: in vivo study of long term treatment in Tg2576 mice. BMC Neurosci 2013, 14:44.

120. Lleo A, Galea E, Sastre M: Molecular targets of non-steroidal anti-inflammatory drugs in neurodegenerative diseases. Cell Mol Life Sci 2007, 64:1403-1418

121. Choi SH, Aid S, Caracciolo L, Minami SS, Niikura T, Matsuoka Y, Turner RS, Mattson MP, Bosetti F: Cyclooxygenase-1 inhibition reduces amyloid pathology and improves memory deficits in a mouse model of Alzheimer's disease. J Neurochem 2013, 124:59-68.

122. Heneka MT, Sastre M, Dumitrescu-Ozimek L, Hanke A, Dewachter I, Kuiperi C, O'Banion K, Klockgether T, Van Leuven F, Landreth GE: Acute treatment with the PPARgamma agonist pioglitazone and ibuprofen reduces glial inflammation and Abeta1-42 levels in APPV717l transgenic mice. Brain 2005, 128:1442-1453.

123. Gomez-Isla T, Blesa R, Boada M, Clarimon J, Del Ser T, Domenech G, Ferro JM, Gomez-Anson B, Manubens JM, Martinez-Lage JM, Muñoz D, Peña-Casanova J, Torres F, TRIMCI Study Group: A randomized, double-blind, placebo controlled-trial of triflusal in mild cognitive impairment: the TRIMCI study. Alzheimer Dis Assoc Disord 2008, 22:21-29.

124. Yan Q, Zhang J, Liu H, Babu-Khan S, Vassar R, Biere AL, Citron M, Landreth G: Anti-inflammatory drug therapy alters beta-amyloid processing and deposition in an animal model of Alzheimer's disease. J Neurosci 2003. 23:7504-7509.

125. Dill J, Patel AR, Yang XL, Bachoo R, Powell CM, Li S: A molecular mechanism for ibuprofen-mediated RhoA inhibition in neurons. J Neurosci 2010, 30:963-972

126. Mandrekar-Colucci S, Karlo JC, Landreth GE: Mechanisms underlying the rapid peroxisome proliferator-activated receptor-gamma-mediated amyloid clearance and reversal of cognitive deficits in a murine model of Alzheimer's disease. J Neurosci 2012, 32:10117-10128.

127. Yamanaka M, Ishikawa T, Griep A, Axt D, Kummer MP, Heneka MT: PPARgamma/RXRalpha-induced and CD36-mediated microglial amyloid-beta phagocytosis results in cognitive improvement in amyloid precursor protein/ presenilin 1 mice. J Neurosci 2012, 32:17321-17331.

128. Dumont M, Stack C, Elipenahli C, Jainuddin S, Gerges M, Starkova N, Calingasan NY, Yang L, Tampellini D, Starkov AA, Chan RB, Di Paolo G, Pujol A Beal MF: Bezafibrate administration improves behavioral deficits and tau pathology in P301S mice. Hum Mol Genet 2012, 21:5091-5105.

129. Searcy JL, Phelps JT, Pancani T, Kadish I, Popovic J, Anderson KL, Beckett TL, Murphy MP, Chen KC, Blalock EM, Landfield PW, Porter NM, Thibault O: Long-term pioglitazone treatment improves learning and attenuates pathological markers in a mouse model of Alzheimer's disease. J Alzheimers Dis 2012, 30:943-961.

130. Hanyu H, Sato T, Kiuchi A, Sakurai H, Iwamoto T: Pioglitazone improved cognition in a pilot study on patients with Alzheimer's disease and mild cognitive impairment with diabetes mellitus. J Am Geriatr Soc 2009, 57:177-179.

131. Risner ME, Saunders AM, Altman JF, Ormandy GC, Craft S, Foley IM, Zvartau-Hind ME, Hosford DA, Roses AD, Rosiglitazone in Alzheimer's Disease Study G: Efficacy of rosiglitazone in a genetically defined population with mild-to-moderate Alzheimer's disease. Pharmacogenomics J 2006, 6:246-254.

132. Noble W, Garwood C, Stephenson J, Kinsey AM, Hanger DP, Anderton BH: Minocycline reduces the development of abnormal tau species in models of Alzheimer's disease. FASEB J 2009, 23:739-750.

133. Familian A, Boshuizen RS, Eikelenboom P, Veerhuis R: Inhibitory effect of minocycline on amyloid beta fibril formation and human microglial activation. Glia 2006, 53:233-240.

134. Ferretti MT, Bruno MA, Ducatenzeiler A, Klein WL, Cuello AC: Intracellular Abeta-oligomers and early inflammation in a model of Alzheimer's disease. Neurobiol Aging 2012, 33:1329-1342.

135. Seabrook TJ, Jiang L, Maier M, Lemere CA: Minocycline affects microglia activation, Abeta deposition, and behavior in APP-tg mice. Glia 2006, 53:776-782

136. Choi Y, Kim HS, Shin KY, Kim EM, Kim M, Kim HS, Park CH, Jeong YH, Yoo J, Lee JP, Chang KA, Kim S, Suh YH: Minocycline attenuates neuronal cell death and improves cognitive impairment in Alzheimer's disease models. Neuropsychopharmacol 2007, 32:2393-2404. 
137. Ryu JK, Franciosi S, Sattayaprasert P, Kim SU, McLarnon JG: Minocycline inhibits neuronal death and glial activation induced by beta-amyloid peptide in rat hippocampus. Glia 2004, 48:85-90.

138. Kobayashi K, Imagama S, Ohgomori T, Hirano K, Uchimura K, Sakamoto K, Hirakawa A, Takeuchi H, Suzumura A, Ishiguro N, Kadomatsu K: Minocycline selectively inhibits M1 polarization of microglia. Cell Death Dis 2013, 4:e525.

139. Ruan L, Kang Z, Pei G, Le Y: Amyloid deposition and inflammation in APPswe/PS1dE9 mouse model of Alzheimer's disease. Curr Alzheimer Res 2009, 6:531-540

140. Shi JQ, Shen W, Chen J, Wang BR, Zhong LL, Zhu YW, Zhu HQ, Zhang QQ, Zhang YD, Xu J: Anti-TNF-alpha reduces amyloid plaques and tau phosphorylation and induces CD11c-positive dendritic-like cell in the APP/PS1 transgenic mouse brains. Brain Res 2011, 1368:239-247.

141. He P, Cheng X, Staufenbiel M, Li R, Shen Y: Long-term treatment of thalidomide ameliorates amyloid-like pathology through inhibition of beta-secretase in a mouse model of Alzheimer's disease. PLoS One 2013, 8:e55091.

142. Tweedie D, Ferguson RA, Fishman K, Frankola KA, Van Praag H, Holloway HW, Luo W, Li Y, Caracciolo L, Russo I, Barlati S, Ray B, Lahiri DK, Bosetti F, Greig NH Rosi S: Tumor necrosis factor-alpha synthesis inhibitor 3,6'-dithiothalidomide attenuates markers of inflammation, Alzheimer pathology and behavioral deficits in animal models of neuroinflammation and Alzheimer's disease. J Neuroinflammation 2012, 9:106.

doi:10.1186/1742-2094-11-25

Cite this article as: Birch et al: Modulation of inflammation in transgenic models of Alzheimer's disease. Journal of Neuroinflammation 2014 11:25.

\section{Submit your next manuscript to BioMed Central and take full advantage of:}

- Convenient online submission

- Thorough peer review

- No space constraints or color figure charges

- Immediate publication on acceptance

- Inclusion in PubMed, CAS, Scopus and Google Scholar

- Research which is freely available for redistribution 